\title{
Effects of organic and inorganic sulphur on the availability of dietary copper to sheep
}

\author{
By N. F. SUTTLE \\ Moredun Research Institute, Edinburgh EHI 7 $7 H$ \\ (Received 31 Fanuary 1974-Accepted I2 March 1974)
}

\begin{abstract}
I. The effects of dietary sulphur on the availability of dietary copper were estimated by means of a repletion technique. The responses of initially hypocupraemic ewes to repletion with $\mathrm{Cu}$-supplemented diets containing supplements of organic $\mathrm{S}$, as methionine, and of inorganic $\mathrm{S}$, as $\mathrm{Na}_{2} \mathrm{SO}_{4}$, were compared with those obtained with a diet low in $\mathrm{S}$.

2. The two forms of $\mathrm{S}$ had similar effects. Responses in plasma $\mathrm{Cu}$ were reduced by $39-56 \%$ when S was increased from $\mathrm{I} \cdot 0$ to $3.0 \mathrm{or} 4.0 \mathrm{~g} / \mathrm{kg}$ diet and the availability of dietary $\mathrm{Cu}$ was estimated to have decreased from 0.062 to $0.04 \mathrm{I}$. Both S supplements produced marked increases in rumen sulphide concentrations.

3. Dietary $\mathrm{S}$ had no effect on plasma $\mathrm{Cu}$ when added to the low-Cu diet of hypocupraemic ewes being repleted by a continuous intravenous infusion of $\mathrm{Cu}$.

4. The addition of $\mathrm{CuS}$, providing $5 \mathrm{mg} \mathrm{Cu} / \mathrm{kg}$, to the diet of hypocupraemic ewes produced no response in plasma $\mathrm{Cu}$ or haemoglobin. The same amount of $\mathrm{Cu}$, given as $\mathrm{CuSO}_{4}$, increased plasma $\mathrm{Cu}$ by $0.46 \pm 0.15 \mathrm{mg} / \mathrm{l}$ and haemoglobin by $33 \pm 3.8 \mathrm{~g} / \mathrm{l}$ after $36 \mathrm{~d}$ : the subsequent replacement of $\mathrm{CuSO}_{4}$ by CuS induced hypocupraemia again but had no effect on haemoglobin.

5. It was concluded that variations in dietary $S$ within the normal range for herbage exert an independent effect on $\mathrm{Cu}$ metabolism, possibly through the formation of insoluble CuS at sites beyond the rumen.
\end{abstract}

Sulphur compounds are broken down extensively by rumen microflora to yield sulphide (Anderson, 1956; Bosman, 1965, 1966) and it has been suggested that the subsequent formation of insoluble copper sulphide in the rumen lowers the availability of dietary $\mathrm{Cu}$ (Dick, r954; Van Koetsveld, r955; Spaïs, 1959). If this hypothesis is valid, one would expect the availability of $\mathrm{Cu}$ to decrease as $\mathrm{S}$ intake increases and organic $\mathrm{S}$ and inorganic sulphate to have similar effects, since both are readily degraded to yield sulphide (Bosman, 1965; Hume \& Bird, 1970). It is also possible that the Cu status of the grazing animal will be determined in part by the $\mathrm{S}$ content of the pasture, which commonly ranges from $r \cdot 0$ to $4^{\circ} \circ \mathrm{g} / \mathrm{kg}$ dry matter (DM) (Whitehead, 1966).

There is at present insufficient experimental evidence with regard to the influence of dietary $\mathrm{S}$ on the $\mathrm{Cu}$ metabolism of ruminants. The effects of organic $\mathrm{S}$ have not been studied despite the fact that some $60-70 \%$ of the $\mathrm{S}$ in herbage exists in the organic form (Furrer, I966; Hartmans, I970) as the constituent $\mathrm{S}$ amino acids of leaf proteins. The evidence with regard to inorganic sulphate is conflicting: in some experiments the addition of sulphate to diets low in molybdenum significantly reduced liver $\mathrm{Cu}$ concentrations in both sheep (Allcroft \& Lewis, 1956; Wynne \& McClymont, I956; Goodrich \& Tillman, I966) and cattle (Mylrea, 1958; Hartmans \& Van der Grift, I964), but in others it had no independent effect on $\mathrm{Cu}$ metabolism (Dick, I953 $a, b$; Marcilese, Ammerman, Valsecchi, Dunavant \& Davis, 1969). A recently developed repletion technique of high sensitivity (Suttle, r974) has therefore been 
used to assess the relative effects of inorganic sulphate and organic $\mathrm{S}$ on the biological availability of $\mathrm{Cu}$ to sheep on a low-Mo diet, and the results are reported in this paper. The technique has also been used to assess the biological availability of CuS to the ruminant, since the initial hypothesis presupposes that $\mathrm{CuS}$, once formed, will remain totally unavailable.

\section{MATERIALS AND METHODS}

\section{Animals and diets}

Sheep were drawn from a pool of forty-five Scottish Blackface ewes, 4-9 years old, as they became hypocupraemic after receiving a low-Cu diet (Suttle, 1974). They were then repleted with a basal diet, consisting mainly of $(\mathrm{g} / \mathrm{kg})$ : oat hulls, 400; dried skim milk, I50; starch, 160; sugar, I60; urea, 20 and arachis oil, 30 together with vitamins and minerals (Suttle \& Field, I968). It contained (per $\mathrm{kg} \mathrm{DM}$ ) : $\mathrm{I}^{\cdot} 5 \mathrm{mg} \mathrm{Cu}$, $0.5 \mathrm{mg} \mathrm{Mo}$ and $\mathrm{r} \cdot \mathrm{O}-\mathrm{I} \cdot 3 \mathrm{~g} \mathrm{~S}$, and various $\mathrm{Cu}$ and $\mathrm{S}$ supplements were added.

\section{Design of experiments}

Expt $\mathrm{x}$. The object of the experiment was to compare the effects of organic and inorganic $\mathrm{S}$ on $\mathrm{Cu}$ availability. Three groups of five hypocupraemic ewes were repleted for $25 \mathrm{~d}$ with a $\mathrm{Cu}$ supplement providing $8 \mathrm{mg} \mathrm{Cu} / \mathrm{kg}$ diet as $\mathrm{CuSO}_{4} \cdot{ }_{5} \mathrm{H}_{2} \mathrm{O}$; one group received a supplement of $\mathrm{r} \cdot 7 \mathrm{~g} \mathrm{~S} / \mathrm{kg}$ diet as $\mathrm{Na}_{2} \mathrm{SO}_{4} \cdot \mathrm{roH}_{2} \mathrm{O}$, another received $2.6 \mathrm{~g} \mathrm{~S} / \mathrm{kg}$ diet as methionine and the third received no $\mathrm{S}$ supplement. The $S$ levels were chosen to represent approximately the amount of each component that would be present in a herbage containing $4 \mathrm{~g}$ total $\mathrm{S} / \mathrm{kg}$, assuming that $65 \%$ of herbage $\mathrm{S}$ is in the organic form (Furrer, 1966; Hartmans, 1970). The experiment commenced as soon as sufficient ewes in the pool had plasma $\mathrm{Cu}$ values below $0.35 \mathrm{mg} / \mathrm{l}$. The ewes were ranked according to their initial plasma $\mathrm{Cu}$ concentrations, the ranking list divided serially into blocks of three and animals allocated at random within blocks to the treatments.

Expt 2. The object of the experiment was to compare equal supplements of inorganic and organic $S$ at a total S level of approximately $4 \mathrm{~g} / \mathrm{kg}$. Three groups each of seven hypocupraemic ewes were repleted for $33 \mathrm{~d}$ with the basal diet supplemented with $4 \mathrm{mg} \mathrm{Cu} / \mathrm{kg}$. One received no S supplement and the others $2.5 \mathrm{~g}$ supplementary $\mathrm{S} / \mathrm{kg}$ diet as either $\mathrm{Na}_{2} \mathrm{SO}_{4}$ or methionine. Ewes were withdrawn from the pool of depleting ewes as they attained plasma $\mathrm{Cu}$ values below $0.30 \mathrm{mg} / \mathrm{l}$ and maintained on a 'standby' diet, containing a supplement of $2 \cdot 0 \mathrm{mg} \mathrm{Cu} / \mathrm{kg}$, until sufficient hypocupraemic ewes were available for the experiment. The ewes were ranked according to the repletion responses observed in a preceding uniformity trial (Suttle, 1974) and allocated to treatments at random as in Expt $\mathrm{I}$.

Expt 3. The apparent effects of $\mathrm{S}$ on $\mathrm{Cu}$ availability observed in Expts $\mathrm{I}$ and 2 could have arisen through systemic effects on the utilization of absorbed $\mathrm{Cu}$ and not on absorption per se. This experiment was designed to determine whether the effect of $\mathrm{S}$ persisted when the $\mathrm{Cu}$ was given by intravenous infusion, thus by-passing the gut. Three hypocupraemic ewes were repleted for $17 \mathrm{~d}$ on two occasions with $0.2 \mathrm{mg}$ $\mathrm{Cu} / \mathrm{d}$ given by continuous intravenous infusion (Suttle, 1974). On the 2nd occasion, 
$3.0 \mathrm{~g} \mathrm{~S} / \mathrm{kg}$ was added to the basal diet to give a dietary $\mathrm{S}$ content of $4.0 \mathrm{~g} / \mathrm{kg}$ compared with $\mathrm{I} \cdot \mathrm{g} / \mathrm{kg}$ on the rst occasion. The pretreatment of the ewes was that described for Expt 2.

Expt 4. The object of the experiment was to confirm that CuS was of low biological availability to sheep. Two groups of four hypocupraemic ewes were repleted for $4 \mathrm{O} \mathrm{d}$ with a diet containing $5 \mathrm{mg}$ supplementary $\mathrm{Cu} / \mathrm{kg}$ diet as either $\mathrm{CuSO}_{4} \cdot{ }_{5} \mathrm{H}_{2} \mathrm{O}$ or $\mathrm{CuS}$ : for a further $36 \mathrm{~d}$, both groups received CuS. The pretreatment of the ewes was the same as that described for Expt $\mathrm{I}$.

In each experiment the daily food allowance of $0.8 \mathrm{~kg} / \mathrm{d}$ was divided equally between two feeds given at 08.30 and 14.30 hours. Ewes were penned individually (Suttle \& Field, 1968) and given deionized water $a d l i b$.

\section{Plasma Cu}

Total $\mathrm{Cu}$ in plasma was determined at frequent (generally weekly) intervals in each experiment by atomic absorption spectrophotometry (Suttle, 1974). The directreacting component of plasma $\mathrm{Cu}$ was generally determined on the first and last days of repletion by the method of Suttle \& Field (1968). Caeruloplasmin Cu was estimated from its oxidase activity either by a ferroxidase method (Expt I; Johnson, Osaki \& Frieden, 1967) or by an automated flow method using $p$-phenylenediamine as substrate (Expt 4 ; Smith \& Wright, I974): results were converted to $\mathrm{IU} / \mathrm{ml}$ on the basis that I IU was equivalent to I $\cdot 6 \mu \mathrm{g}$ caeruloplasmin $\mathrm{Cu}$ (Suttle, I974).

\section{Haemoglobin}

Haemoglobin in whole blood was determined by a cyanmethaemoglobin method described by Suttle (1974).

\section{Rumen sulphide}

Rumen contents were obtained by a stomach tube to which vacuum was applied by means of a $50 \mathrm{ml}$ syringe fitted with a two-way valve: the contents collected in a $5^{0}-100 \mathrm{ml}$ polypropylene tube situated between the stomach tube and valve. Sulphide was determined by the method of Bird \& Fountain (1970) in rumen liquor obtained by filtering rumen contents through muslin. Sulphide was determined on two occasions during Expt 2, at $2 \mathrm{~h}$ and $4 \mathrm{~h}$ after the morning feed on day 27 and day 30 , respectively.

\section{Dietary $S, C u$ and $M o$}

Total S concentrations were determined by $\mathrm{X}$-ray fluorescence and $\mathrm{Cu}$ and $\mathrm{Mo}$ by methods described by Suttle (1974).

\section{Statistical methods}

The results for each experiment were analysed by the conventional technique for randomized block designs (Snedecor, 1956). Treatment means are given with standard errors based on the residual error variance. 


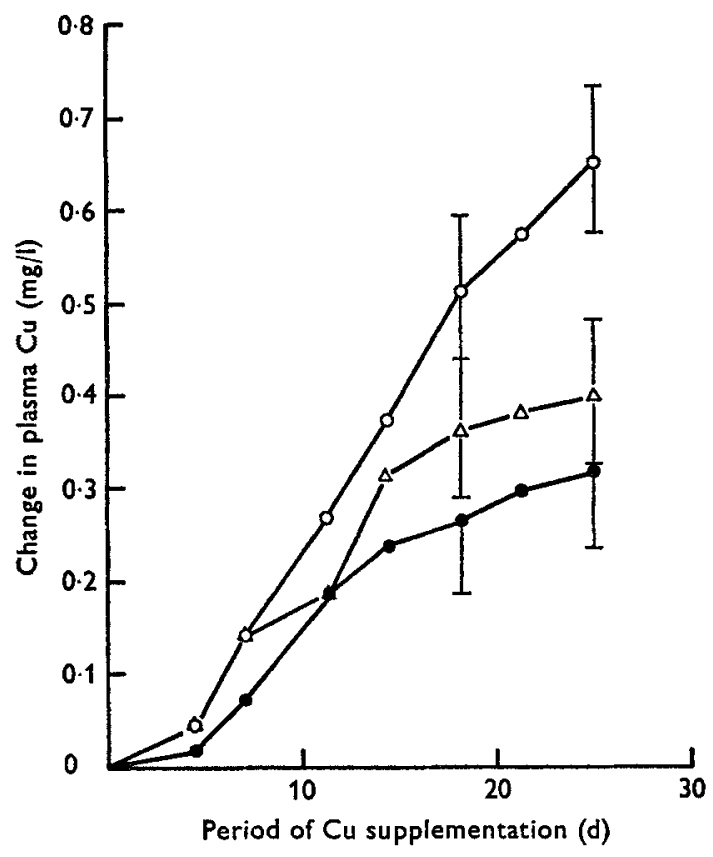

Fig. I. Expt r. Changes in plasma copper levels (mg/l) of initially hypocupraemic ewes given diets containing a standard $\mathrm{Cu}$ supplement $(8 \mathrm{mg} / \mathrm{kg}$ diet $)$ with no added sulphur (O), $2.6 \mathrm{~g} \mathrm{~S}$ as methionine $/ \mathrm{kg}(\odot)$ or $1 \cdot 7 \mathrm{~g} \mathrm{~S}$ as $\mathrm{Na}_{2} \mathrm{SO}_{4} / \mathrm{kg}(\triangle)$. Vertical bar represents SE of mean.

\section{RESULTS}

\section{$\operatorname{Expt} \mathbf{1}$}

Plasma $\mathrm{Cu}$. The addition of $\mathrm{S}$ to the diet as either inorganic sulphate or methionine significantly decreased the response in plasma $\mathrm{Cu}$ (Fig. I). The effect of methionine-S was significant from the I8th day and that of sulphate by the 25th day $(P<0.05)$. The percentage decreases in the final response (i.e. final minus initial value) were large ( $53 \%$ and $38.8 \%$ for methionine-S and sulphate-S, respectively) but the level of significance remained low because of the wide variation within groups, the coefficient of variation being $45 \%$.

The changes in caeruloplasmin $\mathrm{Cu}$ (Fig. 2) generally reflected those in total plasma $\mathrm{Cu}$ although the treatment effects were more marked $(P<0.001$ on day 18$)$. The effects of dietary methionine and inorganic sulphate were evident from days 14 $(P<0.01)$ and $18(P<0.05)$, respectively, and the percentage decreases in the final response were 69 and $47 \%$, respectively.

The direct-reacting component of the plasma $\mathrm{Cu}$ was unaffected by the treatments but showed increases during the repletion $(P<0.01)$ from an initial value of 0.033 to values of $0.052,0.062$ and $0.04 \mathrm{I} \pm 0.004 \mathrm{mg} / \mathrm{l}$ on days I I, $\mathrm{I}_{5}$ and 25 , respectively.

Haemoglobin. Although the ewes were initially hypocupraemic, their haemoglobin levels were normal and remained unaffected by dietary treatment and by repletion in general. 


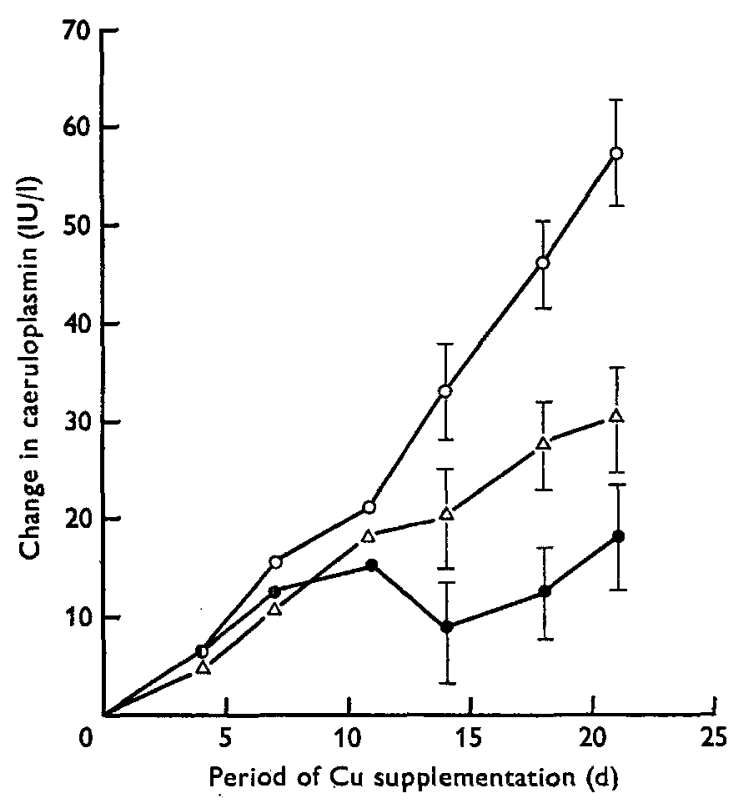

Fig. 2. Expt I. Changes in caeruloplasmin (IU/l) in plasma of initially hypocupraemic ewes given diets containing a standard copper supplement $(8 \mathrm{mg} / \mathrm{kg}$ diet $)$ with no added sulphur $(0), 2.6 \mathrm{~g} \mathrm{~S}$ as methionine $/ \mathrm{kg}(\odot)$ or $\mathrm{I} \cdot 7 \mathrm{~g} \mathrm{~S}$ as $\mathrm{Na}_{2} \mathrm{SO}_{4} / \mathrm{kg}(\triangle)$. Vertical bar represents SE of mean.

\section{Expt 2}

Plasma $\mathrm{Cu}$. The effects of dietary $\mathrm{S}$ supplements on the repletion responses in total plasma $\mathrm{Cu}$, illustrated in Fig. 3, were essentially the same as those shown in Expt I. Organic and inorganic S supplements, providing the same amount of total S $(3.7 \mathrm{~g} / \mathrm{kg})$, were equally effective in reducing the final response by approximately $56 \%(P<0.05)$; the effects of both supplements were significant from day 21. Ewes that had shown the smallest response in an earlier uniformity trial (Suttle, I974; Expt I) again showed the smallest response to repletion, giving a significant difference between blocks $(P<0.05)$. The difference between 'slow' and 'fast' responding ewes was greatest with the unsupplemented diet and the over-all correlation between responses in the uniformity trial and those in Expt 2 was not significant.

The direct-reacting component of the plasma $\mathrm{Cu}$ again increased during the course of repletion: the over-all increase was $0.013 \mathrm{mg} / \mathrm{l}$ and there was no evidence of treatment effects. Caeruloplasmin oxidase activity was not measured.

Rumen sulphide. The mean sulphide concentrations in rumen liquor taken $2 \mathrm{~h}$ after feeding on day 28 were $2 \cdot 3 \mathrm{mg} / \mathrm{l}$ for unsupplemented animals and $\mathbf{1 2} \cdot 8$ and I I. $2 \pm 0.9 \mathrm{mg} / 1$ for those given methionine and inorganic sulphate, respectively; thus the two supplements increased rumen sulphide considerably $(P<0.001)$ and to a similar extent.

Four sheep from each group were also sampled $4 \mathrm{~h}$ after feeding on day 30 . Although the treatment effects were similar, the values obtained for each group were generally lower and far more variable than those found $2 \mathrm{~h}$ after feeding, the mean 


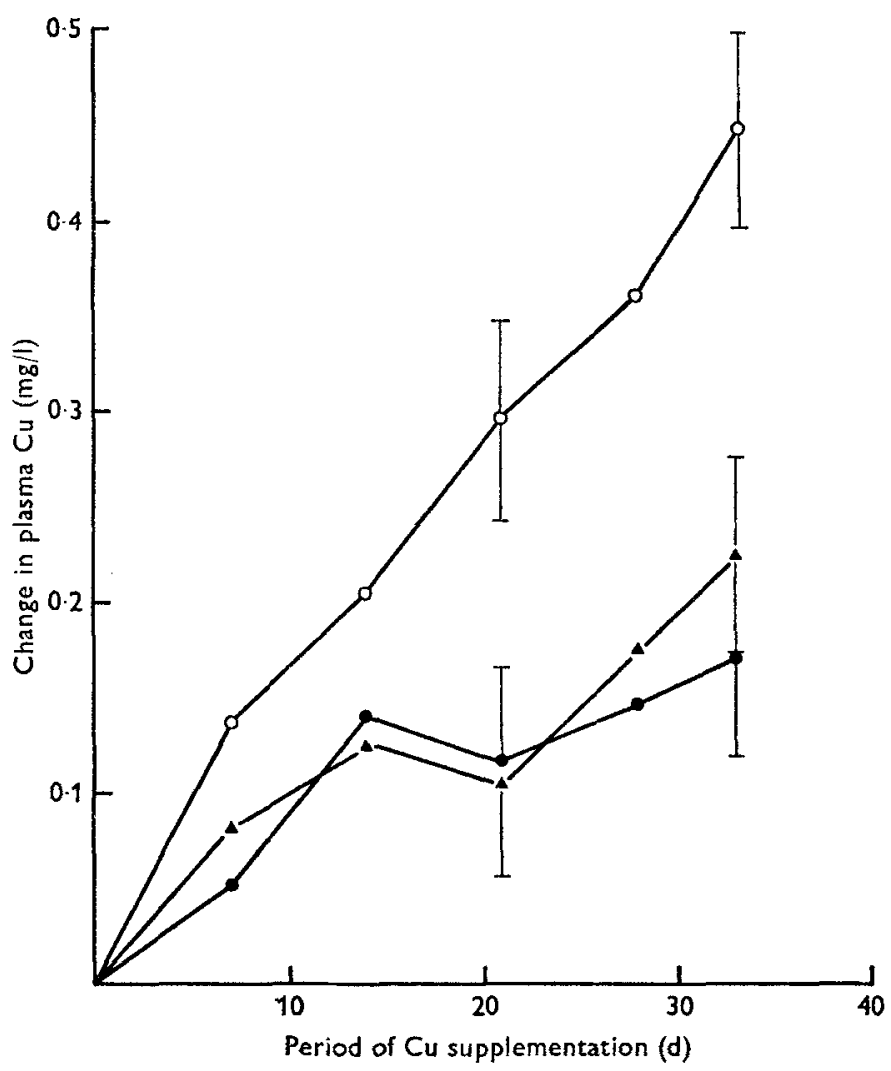

Fig. 3. Expt 2. Changes in plasma copper $(\mathrm{mg} / \mathrm{l})$ of three groups of initially hypocupraemic ewes given diets containing a Cu supplement providing $4 \mathrm{mg} \mathrm{Cu} / \mathrm{kg}$ diet, and no added sulphur (O) or $2.5 \mathrm{~g} \mathrm{~S} / \mathrm{kg}$ as either methionine (e) or $\mathrm{Na}_{2} \mathrm{SO}_{4}(\boldsymbol{A})$. Vertical bar represents SE of mean.

values being $0 \cdot 8,9 \cdot 3$ and $8 \cdot 5 \pm 2 \cdot 6 \mathrm{mg} / 1$ for the groups given no supplement, methionine-S and sulphate-S, respectively.

Haemoglobin. No treatment effects or abnormal values were recorded.

\section{Expt 3}

Plasma $\mathrm{Cu}$. The three ewes repleted by intravenous $\mathrm{Cu}$ infusion showed mean increases of $0.18 \mathrm{I}$ and $0.227 \pm 0.062 \mathrm{mg} / \mathrm{l}$ in plasma Cu after $\mathrm{I} 7 \mathrm{~d}$ when given the low and high-S diets, respectively: the corresponding responses in caeruloplasmin $\mathrm{Cu}$ were 16.2 and $12.5 \pm 3.4 \mathrm{IU} / \mathrm{ml}$. There was thus no significant effect of dietary $\mathrm{S}$ on the $\mathrm{Cu}$ repletion of ewes when the gut was by-passed, although there was a tendency for caeruloplasmin to account for less of the total plasma $\mathrm{Cu}$ response in sulphatesupplemented ewes.

\section{Expt 4}

Plasma Cu. The initial mean values for plasma $\mathrm{Cu}$ were $0.185 \pm 0.045$ and $0.146 \pm$ $0.026 \mathrm{mg} / \mathrm{l}$ in the groups given $\mathrm{CuSO}$, and $\mathrm{CuS}$, respectively. The group given supplementary $\mathrm{Cu}$ as $\mathrm{CuS}$ showed no consistent response in plasma $\mathrm{Cu}$ throughout 


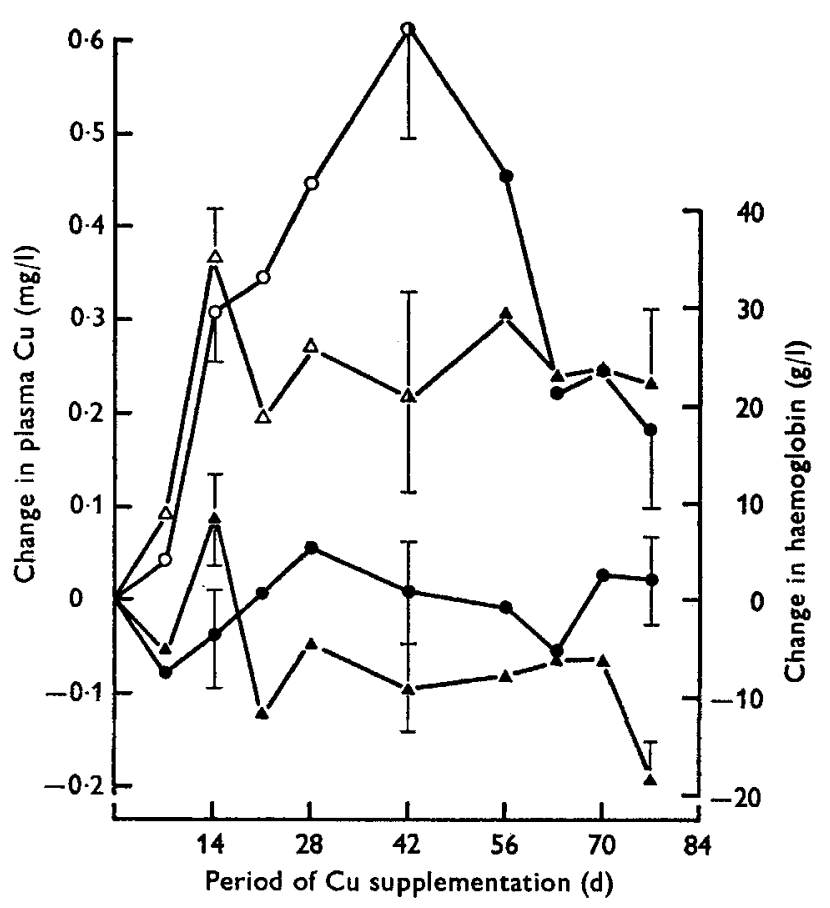

Fig. 4. Expt 4. Changes in plasma copper $(O, \bigcirc \mathrm{mg} / \mathrm{l})$ and haemoglobin $(\triangle, \Delta \mathrm{g} / 1$ whole blood) of two groups of initially hypocupraemic ewes repleted with $5 \mathrm{mg} \mathrm{Cu} / \mathrm{kg}$ diet as either $\operatorname{CuS}(\boldsymbol{\bullet}, \Delta)$ or $\mathrm{CuSO}_{4}(O, \Delta)$. Vertical bar denotes SE of mean.

the $76 \mathrm{~d}$ study (Fig. 4). The group given $\mathrm{Cu}$ as $\mathrm{CuSO}_{4}$, however, showed a gradual increase in plasma $\mathrm{Cu}$ which was significant from the 14 th day. When the $\mathrm{CuSO}_{4}$ was replaced by $\mathrm{CuS}$ after $40 \mathrm{~d}$, plasma $\mathrm{Cu}$ gradually decreased to a final mean value of $0.36 \mathrm{mg} / 1$ after $76 \mathrm{~d}$.

Haemoglobin. The initial haemoglobin values for the groups given $\mathrm{CuSO}_{4}$ and $\mathrm{CuS}$ were $77 \pm \mathrm{I} 6$ and $44 \pm 8 \mathrm{~g} / \mathrm{l}$ whole blood, respectively. Only the group given $\mathrm{Cu}$ as $\mathrm{CuSO}_{4}$ showed a significant increase in haemoglobin level (Fig. 4). The response was complete after $\mathrm{I}_{4} \mathrm{~d}$ and was not reversed when $\mathrm{CuS}$ was substituted for $\mathrm{CuSO}_{4}$ after $40 \mathrm{~d}$.

\section{DISCUSSION}

Increases in the $\mathrm{S}$ content of the diet, as both organic and inorganic $\mathrm{S}$, significantly decreased the efficiency of $\mathrm{Cu}$ utilization in these repletion experiments. Much of the evidence obtained supports the idea that the utilization of $\mathrm{Cu}$ was impaired through the formation of CuS in the gut. The results of Expt 4 showed that CuS, once formed, remains largely unavailable to the sheep as it does to the rat (Schulze, Elvehjem \& Hart, I936) and pig (Bowland, Braude, Chamberlain, Glascock \& Mitchell, 196r). The results of Expt 3 , in which dietary $S$ had no effect on repletion rate when $\mathrm{Cu}$ was given by intravenous infusion, suggest that the site of the $\mathrm{Cu} v . \mathrm{S}$ interaction lies predominantly in the gut. There are, however, theoretical grounds for doubting that the rumen is the critical site for $\mathrm{CuS}$ formation. 
Conditions in the rumen are so favourable for CuS formation that the low solubility product of $\mathrm{CuS}\left(8 \times 10^{-45} \mathrm{~g}\right.$ ion $\left./ 1\right)$ will generally be exceeded and variations in sulphide concentration within physiological limits may have little effect on the extent of $\mathrm{CuS}$ precipitation. For example it would require only a small proportion of the rumen sulphide in unsupplemented animals in Expt $2\left(2 \times 10^{-3} \mathrm{~g} / 1\right)$ to be ionized for ionic $\mathrm{Cu}$ to be almost quantitatively precipitated as CuS. Evidence that this situation existed in the rumen was provided by Bird (1970), who found a negative curvilinear relationship between rumen $\mathrm{S}^{2-}$ and the outflow of soluble $\mathrm{Cu}$ from the rumen, with little further decrease in soluble $\mathrm{Cu}$ outflow at $\mathrm{S}^{2-}$ concentrations above $3 \times \mathrm{IO}^{-3} \mathrm{~g} / \mathrm{l}$. The extent to which $\mathrm{Cu}$ would be dissociated from soluble complexes of low molecular weight under rumen conditions favouring $\mathrm{CuS}$ formation, is, however, impossible to predict and warrants further study.

The critical site for CuS formation is probably farther down the alimentary tract. Although little is known about the metabolism of sulphide beyond the rumen, the fact that sulphide concentrations are as high in omasal as in ruminal digesta after $\mathrm{S}$ supplementation (Bird, 1970) and that $\mathrm{CuS}$ is very insoluble at a $\mathrm{pH}$ of 2 , suggests that any soluble $\mathrm{Cu}$ released during digestion in the omasum and possibly the abomasum will continue to be largely precipitated as $\mathrm{CuS}$. It is interesting to note that Bremner (1970) observed a decrease in solubility of $\mathrm{Cu}$ in the digesta between the rumen and abomasum in sheep given dried grass. It is conceivable, therefore, that $\mathrm{S}$ supplementation influences the availability of $\mathrm{Cu}$ by extending the region of the alimentary tract in which conditions favour $\mathrm{CuS}$ formation. More needs to be known about sulphide concentrations at sites beyond the omasum and about the critical sites for $\mathrm{Cu}$ absorption in ruminants to clarify the situation.

$\mathrm{S}$ may also interfere with $\mathrm{Cu}$ metabolism by other pathways. Hume \& Bird (1970) have shown that the outflow of microbial protein from the rumen is increased by $15 \%$ when $\mathrm{S}$ intakes are increased to levels similar to those used in the present studies. Since a major proportion of the insoluble $\mathrm{Cu}$ in the rumen appears to be associated with the microflora (Bremner, $\mathrm{r} 970$ ) it is possible that $\mathrm{S}$ partly reduces the availability of $\mathrm{Cu}$ by increasing the formation of 'microbial $\mathrm{Cu}$ ' from which $\mathrm{Cu}$ is poorly absorbed. Bird (1970) found that ionic $\mathrm{Cu}$ added to sulphide-free strained rumen fluid was extensively precipitated with the particulate matter during centrifugation.

When the effects of dietary $\mathrm{S}$ on plasma $\mathrm{Cu}$ repletion were converted to units of available Cu by the method outlined by Suttle (1974), it was estimated that $\mathrm{S}$ reduced the true availability ratio of $\mathrm{Cu}$ from 0.058 to 0.040 in Expt I and from 0.074 to 0.042 in Expt 2. Requirements for Cu were thus increased by approximately $50 \%$ by increasing the $\mathrm{S}$ content of the diet from the lower to the upper limit of the normal range for herbage $S(\mathrm{I} \cdot 0-4 \cdot 0 \mathrm{~g} / \mathrm{kg}$, Whitehead, 1966$)$. The majority of workers who have investigated the effect of dietary $\mathrm{S}$ on the Cu status of ruminants have recorded an impairment of $\mathrm{Cu}$ utilization (Allcroft \& Lewis, 1956 ; Wynne \& McClymont, 1956; Mylrea, 1958; Hartmans \& Van der Grift, 1964; Goodrich \& Tillman, 1966) and those who observed no effect used relatively small $S$ supplements $(<2 \mathrm{~g} / \mathrm{kg}$; Dick, 1953 $a, b$; Marcilese et al. 1969). Provided that the experimental treatments in the 
above studies have simulated conditions pertaining to the grazing animal it would appear that commonly encountered variations in herbage $\mathrm{S}$ will influence the $\mathrm{Cu}$ status of the grazing animal. Under conditions of low $\mathrm{Cu}$ concentration or availability or both, an effect of S superimposed could be sufficient to induce clinical deficiency in both sheep and cattle.

There are two reports in the literature of associations between pasture $S$ and the $\mathrm{Cu}$ status of the grazing animal. Hartmans \& Van der Grift (I964) found a significantly higher $\mathrm{S}$ concentration, 3.7 v. $2.8 \mathrm{~g} / \mathrm{kg}$, on farms where cattle showed a relatively fast decline in liver $\mathrm{Cu}$ stores during the grazing season. The occurrence of swayback on some coastal pastures in Greece has been attributed to the ingestion of sulphate-rich halophytes containing $6 \mathrm{~g} \mathrm{~S} / \mathrm{kg} \mathrm{DM}$ (Spais, I959). More extensive investigations may reveal a widespread influence of herbage $S$ on the $\mathrm{Cu}$ status of the grazing animal. Furthermore, the increase in $\mathrm{Cu}$ status which commonly occurs when ruminants are housed during winter or reared intensively may be partly explained by the relatively low concentrations of $\mathrm{S}$ in cereals (Todd, 1972) and the relatively low yields of sulphide from conserved forages (Bosman, 1965, I966; Hartmans \& Bosman, I970).

I thank Dr A. C. Field for his advice and encouragement, Mr D. M. Pollock for preparing diets, Mrs M. MacDonald and Mr J. Cruickshank for tending the sheep and Mrs. J Williams and Mr J. Small for their technical assistance. I am also indebted to $\mathrm{Mr} \mathrm{B}$. Mitchell and $\mathrm{Mr}$ J. Williams, who inserted the jugular catheters, and to Dr C. Evans from the Hill Farming Research Organisation, Edinburgh, who estimated $\mathrm{S}$ in the diets.

\section{REFERENCES}

Allcroft, R. \& Lewis, G. (1956). Landbouwk. Tijdschr., 's-Grav. 68, 7 I I.

Anderson, C. (1956). N. Z. Fl Sci. Technol. 37, 379 .

Bird, P. R. (r 970). Proc. Aust. Soc. Anim. Prod. 8, 212.

Bird, P. R. \& Fountain R. D. (r970). Analyst, Lond. 95, 98.

Bosman, M. S. M. (1965). Jaarb. Inst. biol. scheik. Onderz. LandbGewass. p. 97.

Bosman, M. S. M. (I966). Faarb. Inst, biol. scheik. Onderz. LandbGewass. p. 73.

Bowland, J. P., Braude, R., Chamberlain, A. G., Glascock, R. F. \& Mitchell, K. G. (I96ı). Br. F. Nutr. 15, 59 .

Bremner, I. (1970). Br. F. Nutr. 24, 769.

Dick, A. T. (1953a). Aust. vet. F. 29, I8.

Dick, A. T. (1953b). Aust. vet. F. 29, 233.

Dick, A. T. (1954). Aust. F. agric. Res. 5, 511.

Furrer, O. J. (1966). Schweiz. Landw. Mh. 44, 125.

Goodrich, R. D. \& Tillman, A. D. (1966). F. Anim. Sci. 25, 484.

Hartmans, J. (1970). In Trace Element Metabolism in Animals p. 44r [C. F. Mills, editor]. Edinburgh: E. \& S. Livingstone.

Hartmans, J. \& Bosman, M. S. M. (1970). In Trace Element Metabolism in Animals p. 362 [C. F. Mills, editor]. Edinburgh: E. \& S. Livingstone.

Hartmans, J. \& Van der Grift, J. (1964). Faarb. Inst. biol. scheik. Onderz. LandbGewass. p. I45.

Hume, I. D. \& Bird, P. R. (1970). Aust. F. agric. Res. 2r, 3 I 5.

Johnson, D. A., Osaki, S. \& Frieden, E. (1967). Clin. Chem. 13, r42.

Marcilese, N. A., Ammerman, C. B., Valsecchi, R. M., Dunavant, B. G. \& Davis, G. K. (I969). F. Nutr. 99, I77.

Mylrea, P. J. (1958). Aust. F. agric. Res. 9, 383.

Schulze, M. O., Elvehjem, C. A. \& Hart, E. B. (1936). F. biol. Chem. Ir5, 453.

Smith, B. S. W. \& Wright, H. (1974). Clinica Chim. Acta (In the Press.) 
Snedecor, G. W. (1956). Statistical Methods Applied to Experiments in Agriculture and Biology 5 th ed., p. 291. Ames, Iowa: Iowa State College Press.

Spaïs, A. G. (1959). Ask. vet. Derg. 135, r6r.

Suttle, N. F. (1974). Br. F. Nutr. 32, 365.

Suttle, N. F. \& Field, A. C. (r968). 7 . Comp. Path. Ther. 78, 35 I.

Todd, J. R. (I972). Y. agric. Sci., Camb. 79, I9I.

Van Koetsveld, E. (r955). Tijdschr. Diergeneesk. 80, 525.

Whitehead, D. C. (1966). Rep. Grassld. Res. Inst. no. 4, p. 21.

Wynne, K. N. \& McClymont, G. L. (1956). Aust. F. agric. Res. 7, 45. 